GRASAS Y ACEITES 71 (1)

January-March 2020, e341

ISSN-L: 0017-3495

https://doi.org/10.3989/gya.1176182

\title{
Sulphur doses and application times on yield and oil quality of canola grown in calcareous soil
}

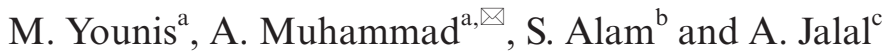 \\ ${ }^{\mathrm{a}}$ Department of Agronomy, The University of Agriculture Peshawar, Pakistan. \\ ${ }^{b}$ Department of Agriculture Chemistery, The University of Agriculture Peshawar, Pakistan. \\ 'Institute of Biotechnology \& Genetic Engineering, The University of Agriculture Peshawar, Pakistan. \\ Corresponding author: asimmuh@aup.edu.pk
}

SUMMARY: Pakistan has been constantly deficient in its oil seed production and it is very difficult to meet the edible oil requirement of its ever-increasing population. A field experiment was conducted at the Agronomy Research Farm, The University of Agriculture Peshawar, Northern Pakistan during winter (2013-14). Five sulphur levels $\left(15,30,45,60\right.$ and $\left.75 \mathrm{~kg} \cdot \mathrm{ha}^{-1}\right)$ and times of application (at seedling, bolting and flowering stages) were used for the canola variety Abasin-95. The experiment was laid out in a randomized complete block design replicated four times on a $5 \mathrm{~m} \times 3.2 \mathrm{~m}$ plot size. The results showed that the sulphur-applied plots gave the highest seed yield, biological yield, glucosinolate, erucic acid, oil content, protein content, oleic acid and linoleic acid compared to the control plots. Sulphur applied at the rate of $60 \mathrm{~kg} \cdot \mathrm{ha}^{-1}$ and applied at the bolting stage increased seed yield, biological yield, oil content, and protein content.

KEYWORDS: Canola; Linoleic acid; Oil; Oleic acid; Production; Protein; Sulphur

RESUMEN: Dosis de azufre y tiempos de aplicación en el rendimiento y la calidad del aceite de canola cultivada en suelo calcáreo. Pakistán ha sido constante y crónicamente deficiente en producción de semillas oleaginosas y es muy difícil cumplir con la demanda de aceites comestibles para una población cada vez mayor. Se realizó un experimento de campo en la granja de investigación agronómica de la Universidad de Agricultura Peshawar, en el norte de Pakistán, durante el invierno (2013-14). Los cinco niveles de azufre (15, 30, 45, 60 y $\left.75 \mathrm{~kg} \cdot \mathrm{ha}^{-1}\right)$ y su tiempo de aplicación (en las etapas de plántula, floración y floración) se utilizaron para la variedad de canola (Abasin-95). El experimento se realizó en un diseño de bloques completos al azar que se replicó cuatro veces con un tamaño de parcela de $5 \mathrm{~m} \times 3,2 \mathrm{~m}$. Los resultados mostraron que las parcelas aplicadas con azufre dieron el mayor rendimiento de semilla, rendimiento biológico, glucosinolato, ácido erúcico, contenido de aceite, contenido de proteína, ácido oleico y ácido linoleico en comparación con las parcelas de control. El azufre se aplicó en una tasa de $60 \mathrm{~kg} \cdot \mathrm{ha}^{-1}$ y se aplicó en la etapa de empernado, incrementando el rendimiento de las semillas, el rendimiento biológico, el contenido de aceite y el contenido de proteínas.

PALABRAS CLAVE: Aceite; Ácido linoleico; Ácido oleico; Azufre; Canola; Producción; Proteína

ORCID ID: Younis M https://orcid.org/0000-0002-8547-7478, Muhammad A https://orcid.org/0000-0002-4018-4014, Alam S https://orcid.org/0000-0002-1620-6033, Jalal A https://orcid.org/0000-0002-0218-5171

Citation/Cómo citar este artículo: Younis M, Muhammad A, Alam S, Jalal A. 2020. Sulphur doses and application times on yield and oil quality of canola grown in calcareous soil. Grasas Aceites 71 (1), e341. https://doi.org/10.3989/ gya.1176182

Copyright: C2020 CSIC. This is an open-access article distributed under the terms of the Creative Commons Attribution 4.0 International (CC BY 4.0) License. 


\section{INTRODUCTION}

Canola is an important oil seed crop of Cruciferae (Holmes, 1980). Rapeseed is grown as an oil seed crop and also as a fodder crop in the Indus Valley c. 300 BC (Wiess, 1983). Vegetable oils are rich sources of erucic acid and glucosinolate (sulphur compounds) in the tissues, which give a bitter taste which can be unpleasant and even toxic (Muhammad et al., 1991). The desirable range of erucic acid and glucosinolate in canola oil are $2 \%$ erucic acid and $30 \mu \mathrm{mol} \cdot \mathrm{g}^{-1}$ glucosinolates in oil (Grombacher and Nelson, 1992). After palm and soybean, Canadian plant breeders have reduced these compounds to an acceptable level by converting rapeseed species to canola as the world's third most commonly consumed vegetable oil (Rękas et al., 2017). In agriculturally advanced countries, economic conditions demand higher crop yields to meet the high profit that comes from oil crops and population growth (Sawan et al., 2007).

The average yield of canola in Pakistan is very low $\left(922 \mathrm{~kg} \cdot \mathrm{ha}^{-1}\right)$ and its average yield in northern Pakistan is $452 \mathrm{~kg} \cdot \mathrm{ha}^{-1}$ (MNFS\&R, 2013-14). In Pakistan, canola is cultivated in an area of 238900 ha and in northern Pakistan in an area of 18800 ha. The annual seed production of canola is 220300 tones in Pakistan, while in northern Pakistan 8500 tones (MNFS\&R, 2013-14). Canola was cultivated in an area of 586 thousand acres with seed production of 218 thousand tonnes and 68 thousand tonnes oil yield (GOP, 2014). In the northwest frontier of Pakistan (Khyber Pakhtunkhwa Province) canola mainly cultivated on marginal lands or river bank fields. Therefore, farmers cannot obtain maximum yield due to nutrient deficiencies and low soil fertility.

Fertilizers always play an important role in increasing many crop yields as a result of sufficient nutrition availability to the crops. Sulphur has prime importance in the synthesis of chlorophyll and oil in canola. It plays an important role in chemical composition as well as seed oil content (Hassan et al., 2007). During deficient conditions of sulphur the crop production may not be sustainable and seriously affected by applied NPK fertilizer efficiency (Ahmad et al., 1994). Previous studies have shown sulphur nutrition to have different effects on the seed production and oil quality of the canola crop when applied at different growth stages. The application of $20 \mathrm{~kg} \cdot \mathrm{ha}^{-1}$ sulphur at sowing time improved the oil content, glucosinolate and protein content of canola (Ahmad et al., 1994; Jan et al., 2008). Non destructive methods for the oil determination of rapeseed have the advantages of being rapid and relatively more environmentally friendly since they require minimum sample preparation (Uncu et al., 2019).
Keeping in mind the importance of sulphur both for improving the seed production and oil quality of canola, the present research was aimed to assess the effects of sulphur nutrition levels and sulphur application timing on the yield and oil quality of canola in the calcareous soils of northern Pakistan.

\section{MATERIALS AND METHODS}

\subsection{Experimental treatments and design}

In order to study the effect of sulphur nutrition levels and time of application on seed yield and oil quality of canola, an experiment was undertaken at the Agronomy Research Farm, The University of Agriculture Peshawar (2013-2014). The experiment consisted of five sulphur levels $(\mathrm{S} 1=15, \mathrm{~S} 2=30, \mathrm{~S} 3=$ $\left.45, \mathrm{~S} 4=60, \mathrm{~S} 5=75 ; \mathrm{kg} \cdot \mathrm{ha}^{-1}\right)$ and three different application times $(\mathrm{AT} 1=$ application at seedling growth stage, AT2 = application at bolting growth stage and AT3 = application at flowering growth stage). In addition, a control was maintained with each of the replicated treatments (no sulphur application was made). A randomized complete block design was used and replicated four times. Ammonium sulphate $\left(\mathrm{NH}_{4} \mathrm{SO}_{4}\right)$ from the Fuji fertilizer private Ltd, Lahore, Pakistan was used as the source of sulphur. Canola seeds (Abasin-95) were provided by the Nuclear Institute for Food and Agriculture, Pakistan and sown in winter. $5 \mathrm{~m} \times 3.2 \mathrm{~m}$ plots were made and replicated, consisting of 8 rows with $0.4 \mathrm{~m}$ rowto-row distance. Phosphorus $\left(50 \mathrm{~kg} \cdot \mathrm{ha}^{-1}\right)$ was applied during sowing in the form of single super phosphate, and nitrogen $\left(75 \mathrm{~kg} \cdot \mathrm{ha}^{-1}\right)$ was applied in the form of urea (half dose during sowing time and half dose during flowering stage) after subtracting the amount of nitrogen supplied through ammonium sulphate. After complete emergence, hand thinning was done at the four leaf stage, maintaining 50 plants per row. All other cultural practices, including irrigation, weeding and hoeing etc. were carried out uniformly in all the plots. An average soil analyses of the experimental site showed a sandy loam texture, $\mathrm{pH}$ (7.4), EC $\left(0.204 \mathrm{dS} \cdot \mathrm{m}^{-1}\right)$, bulk density $\left(1.52 \mathrm{~g} \cdot \mathrm{cm}^{-3}\right)$, moisture $(7.8 \%)$, organic matter $\left(0.50 \mathrm{mg} \cdot \mathrm{kg}^{-1}\right)$, phosphorous $\left(0.45 \mathrm{mg} \cdot \mathrm{kg}^{-1}\right)$ and low sulphur $\left(0.035 \mathrm{mg} \cdot \mathrm{kg}^{-1}\right)$ at $0-15 \mathrm{~cm}$ depth. Mean maximum, minimum temperature $\left({ }^{\circ} \mathrm{C}\right)$, humidity $(\%)$ and rainfall $(\mathrm{mm})$ for the growing period of the canola crop are presented in Figure 1. The experiment was carried out from October 2013 to May 2014. Seed yield $\left(\mathrm{kg} \cdot \mathrm{ha}^{-1}\right)$ was determined in each of the replicated plots where the four central rows were harvested at maturity and dried under sun light, manually threshed, weighed and coverted to $\mathrm{kg} \cdot \mathrm{ha}^{-1}$.

Biological yield $\left(\mathrm{kg} \cdot \mathrm{ha}^{-1}\right)$ was calculated after harvesting the four central rows in each of the replicated plots at harvest maturity of the canola crop, dried under sun light, weighed and converted in $\mathrm{kg} \cdot \mathrm{ha}^{-1}$. 


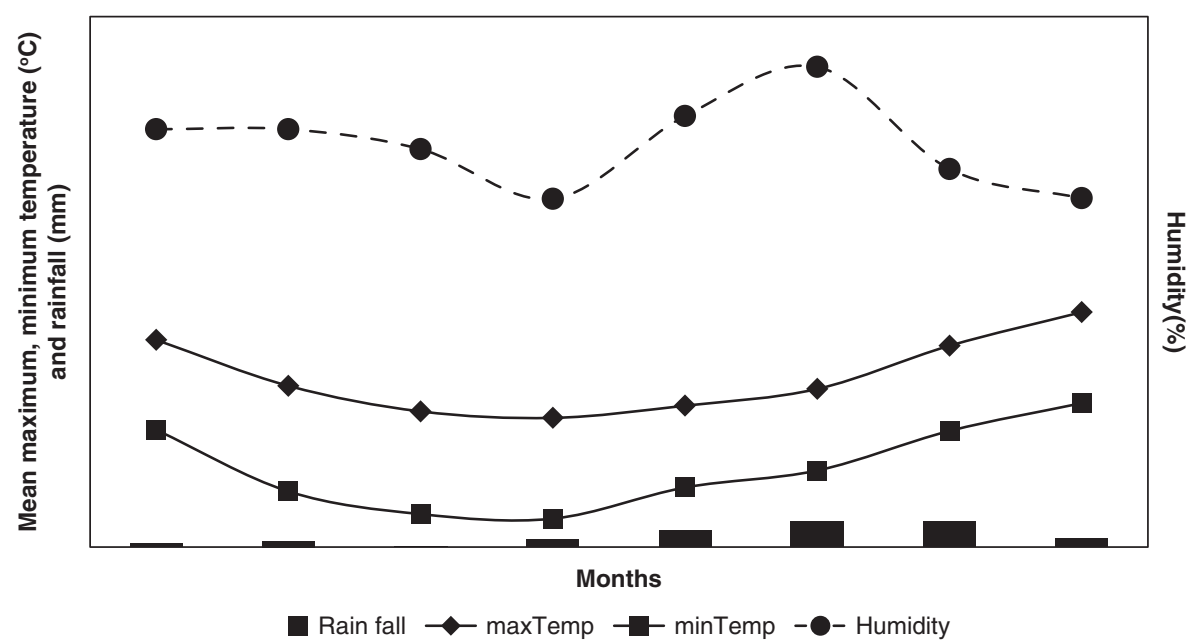

FIgURE 1. Mean minimum, maximum temperature $\left({ }^{\circ} \mathrm{C}\right)$, humidity $(\%)$ and rainfall $(\mathrm{mm})$ for the growing period of canola (2013-14).

Biological yield of the

$\begin{gathered}\text { Biological } \\ \text { yield }\left(\mathrm{kg} \mathrm{ha}^{-1}\right)\end{gathered}=\frac{\text { harvested rows }}{\begin{array}{c}\text { Row }- \text { row distance } \times \\ \text { row length } \times \text { no. of rows }\end{array}} \times 10000$

\subsection{Seed quality parameters}

To determine the glucosinolate $\left(\mu \mathrm{mol} \mathrm{g}^{-1}\right)$, erucic acid $(\%)$, oil content $(\%)$, protein content $(\%)$, oliec acid $(\%)$ and linoliec acid (\%) in the canola seed, a five (5) gram sample obtained from each treatment plot was analyzed by a Near Infra-red Reflectance Spectroscopy System, (TR-3657-C Model 6500) as described by Ahmad et al., (2015) at Oilseed Quality Laboratory, Crop Breeding Division, Nuclear Institute for Food and Agriculture Peshawar, Pakistan.

\subsection{Statistical analysis}

The recorded data was statistically analyzed according to the analysis of variance techniques used for randomized complete block design and least significant difference (LSD) was applied at a $5 \%$ level of significance $(\mathrm{P} \leq 0.05)$ upon significant F-test through the procedure described by Jan et al., (2009).

\section{RESULTS AND DISCUSSION}

\subsection{Weather data}

During the growing season the temperature ranged from $11.8^{\circ} \mathrm{C}$ minimum to $25.8^{\circ} \mathrm{C}$ maximum (Figure 1). Relative humidity ranged from 52.5 to
$72.4 \%$, while total rainfall was recorded as $14.1 \mathrm{~mm}$. It is clear that minimum and maximum temperature gradually decreased from October to January and then increased. Maximum rainfall was recorded in March (3.9mm) and April (3.8mm).

\subsection{Seed yield $\left(\mathrm{kg} \cdot \mathrm{ha}^{-1}\right)$}

Seed is the ultimate output of a crop which determines the profitability of the crop production enterprise. Sulphur levels and time of sulphur application had significant effects on the seed yield of canola and their interaction was found to be non significant (Table 1). Sulphur application increased seed yield compared to the control. Higher seed yield $\left(2452 \mathrm{~kg} \cdot \mathrm{ha}^{-1}\right)$ was recorded in plots where $60 \mathrm{~kg} \cdot \mathrm{ha}^{-1}$ sulphur were applied as compared to the $15 \mathrm{~kg} \cdot \mathrm{ha}^{-1}$ sulphur plots $\left(1376 \mathrm{~kg} \cdot \mathrm{ha}^{-1}\right)$. These results are in agreement with Chauhan et al.,(1996), who reported that sulphur increased the seed yield of rapeseed. The findings of Begum et al., (2012) revealed that sulphur up to $60 \mathrm{~kg} \cdot \mathrm{ha}^{-1}$ application produced a higher seed yield of canola. Sulphur application timings had significantly affected the seed yield. More seed yield $\left(1998 \mathrm{~kg} \cdot \mathrm{ha}^{-1}\right)$ was obtained at the bolting stage, while lower seed yield was obtained when sulphur was applied at seedling and bolting stages (1907 and $1922 \mathrm{~kg} \cdot \mathrm{ha}^{-1}$, respectively). The crops grown in sulphur fertilized plots obtained higher seed yield $\left(1942 \mathrm{~kg} \cdot \mathrm{ha}^{-1}\right)$, while lower seed yield $\left(1134 \mathrm{~kg} \cdot \mathrm{ha}^{-1}\right)$ was recorded from the control plots. Canola seed yield was increased when sulphur was applied at the rate of $40 \mathrm{~kg} \cdot h a^{-1}$ (Varényiová et al., 2017). The findings of Malhi and Gill (2002); Malhi and Leach (2000) indicated that the seed yield of canola was lower when sulphur was applied at the flowering stage compared to that obtained when sulphur was applied at the bolting stage. Hocking 
et al., (1996) also found that sulphur applied at bolting resulted in the same yield although there was significant reduction in seed yield when sulphur application was delayed until the flowering stage. The interaction between $\mathrm{S} \times \mathrm{AT}$ revealed non significant effects on seed yield (Table 6).

\subsection{Biological yield $\left(\mathrm{kg} \cdot \mathrm{ha}^{-1}\right)$}

The data revealed that sulphur levels have a significant effect on the biological yield of canola (Table 1). Increasing sulphur rates up to 60 $\mathrm{kg} \cdot \mathrm{ha}^{-1}$ significantly increased the biological yield. Maximum biological yield $\left(11461 \mathrm{~kg} \cdot \mathrm{ha}^{-1}\right)$ was obtained from $60 \mathrm{~kg}$ sulphur $\cdot \mathrm{ha}^{-1}$ followed by 75 $\mathrm{kg}$ sulphur $\mathrm{ha}^{-1}$ (Table. 3). A higher cofficient of variation (12.03) was seen in the biological yield (Table 7). Collectively, the highest biological yield $\left(10574 \mathrm{~kg} \cdot \mathrm{ha}^{-1}\right)$ was recorded in the sulphur-treated plots compared to the control plots $\left(8469 \mathrm{~kg} \cdot \mathrm{ha}^{-1}\right)$. The application timings and interaction of $\mathrm{S} \times \mathrm{AT}$ had no significant effect on biological yield. These results are comparable to those of Khandkar et al., (1991) in that biological yield was enhanced significantly with the application of sulphur levels. Malik et al., (2004) also reported that biological yield was significantly affected by sulphur levels.

\subsection{Glucosinolate $\left(\mu \mathrm{mol} \cdot \mathrm{g}^{-1}\right)$}

The glucosinolate content of canola as influenced by various sulphur levels and application times is presented in Table 2. The statistical analysis of data showed a significant effect of sulphur levels on the glucosinolate of canola. Average values for the data showed that significantly higher glucosinolate $\left(31.2 \mu \mathrm{mol} \cdot \mathrm{g}^{-1}\right)$ was obtained from $75 \mathrm{~kg}$ sulphur ha $^{-1}$ treated plots, whereas minimum glucosinolate $\left(19.7 \mu \mathrm{mol} \cdot \mathrm{g}^{-1}\right)$ was obtained from $15 \mathrm{~kg}$ sulphur ha $^{-1}$ plots. Application times and interaction of sulphur $\mathrm{x}$ application times was found non significant (Table 5). The sulphur levels showed a positive influence on the glucosinolate content of canola. Mailer (1989) reported that sulphur was essential up to some level for normal plant growth and affected the glucosinolate content of canola. It was also elaborated that a sulphur deficiency lowered glucosinolate content in control plots. Wang et al., (1997) also determined that an increase in sulphur application enhanced the glucosinolate content of canola.

TABLE 1. Seed yield $\left(\mathrm{kg} \cdot \mathrm{ha}^{-1}\right)$ and biological yield $\left(\mathrm{kg} \cdot \mathrm{ha}^{-1}\right)$ of canola as affected by sulphur levels and application times

\begin{tabular}{|c|c|c|c|c|c|c|c|c|c|c|c|c|}
\hline \multirow{3}{*}{$\begin{array}{l}\text { Application } \\
\text { times (AT) }\end{array}$} & \multicolumn{6}{|c|}{ Seed yield $\left(\mathrm{kg} \cdot \mathrm{ha}^{-1}\right)$} & \multicolumn{6}{|c|}{ Biological yield $\left(\mathrm{kg}^{\prime} \mathrm{ha}^{-1}\right)$} \\
\hline & \multicolumn{6}{|c|}{ Sulphur $\left(\mathrm{kg} \cdot \mathrm{ha}^{-1}\right)$} & \multicolumn{6}{|c|}{ Sulphur $\left(\mathrm{kg} \cdot \mathrm{ha}^{-1}\right)$} \\
\hline & 15 & 30 & 45 & 60 & 75 & Mean & 15 & 30 & 45 & 60 & 75 & Mean \\
\hline Seedling & 1318 & 1540 & 1979 & 2421 & 2278 & $1907^{b}$ & 9363 & 9121 & 10600 & 11548 & 10788 & 10284 \\
\hline Bolting & 1469 & 1630 & 2023 & 2526 & 2342 & $1998^{\mathrm{a}}$ & 10198 & 10863 & 10025 & 11513 & 11850 & 10890 \\
\hline Flowering & 1340 & 1581 & 1974 & 2408 & 2306 & $1922^{\mathrm{b}}$ & 9796 & 10125 & 10713 & 11325 & 10788 & 10549 \\
\hline Mean & $1376^{\mathrm{e}}$ & $1584^{\mathrm{d}}$ & $1992^{\mathrm{c}}$ & $2452^{\mathrm{a}}$ & $2309^{b}$ & & $9785^{\mathrm{b}}$ & $10036^{\mathrm{b}}$ & $10446^{\mathrm{ab}}$ & $11462^{\mathrm{a}}$ & $11142^{\mathrm{a}}$ & \\
\hline Control & 1134 & Lsd & Sulphur & \multicolumn{2}{|c|}{ AT } & SxAT & Control & 8469 & Lsd & Sulphur & AT & SxAT \\
\hline Fertilized & 1942 & 0.05 & 35.67 & \multicolumn{2}{|c|}{27.63} & ns & Fertilized & 10574 & 0.05 & 1033 & ns & ns \\
\hline
\end{tabular}

$\mathrm{S}=$ Sulphur, AT= Application times, $\mathrm{SxAT}=$ Sulphur $\mathrm{x}$ Application times, $\mathrm{ns}=$ non significant, $\mathrm{Lsd}=$ Least significant difference test

TABLE 2. Glucosinolate $\left(\mu \mathrm{mol} \cdot \mathrm{g}^{-1}\right)$ and erucic acid $(\%)$ of canola as affected by sulphur levels and application times

\begin{tabular}{|c|c|c|c|c|c|c|c|c|c|c|c|c|}
\hline \multirow{3}{*}{$\begin{array}{l}\text { Application } \\
\text { times (AT) }\end{array}$} & \multicolumn{6}{|c|}{ Glucosinolate $\left(\mu \mathrm{mol} \cdot \mathrm{g}^{-1}\right)$} & \multicolumn{6}{|c|}{ Erucic acid (\%) } \\
\hline & \multicolumn{6}{|c|}{ Sulphur $\left(\mathrm{kg} \cdot \mathrm{ha}^{-1}\right)$} & \multicolumn{6}{|c|}{ Sulphur $\left(\mathrm{kg} \cdot \mathrm{ha}^{-1}\right)$} \\
\hline & 15 & 30 & 45 & 60 & 75 & Mean & 15 & 30 & 45 & 60 & 75 & Mean \\
\hline Seedling & 19.7 & 23.6 & 25.5 & 25.5 & 29.8 & 24.8 & 1.3 & 1.4 & 1.5 & 1.7 & 2.1 & 1.6 \\
\hline Bolting & 20.0 & 23.8 & 23.8 & 25.5 & 31.3 & 24.9 & 1.3 & 1.5 & 1.5 & 1.6 & 2.1 & 1.6 \\
\hline Flowering & 19.5 & 23.4 & 23.3 & 24.2 & 32.4 & 24.6 & 1.4 & 1.5 & 1.6 & 1.6 & 2.1 & 1.6 \\
\hline Mean & $19.7^{\mathrm{c}}$ & $23.6^{\mathrm{b}}$ & $24.2^{\mathrm{b}}$ & $25.1^{\mathrm{b}}$ & $31.2^{\mathrm{a}}$ & & $1.3^{\mathrm{d}}$ & $1.4^{\text {cd }}$ & $1.5^{\mathrm{bc}}$ & $1.6^{\mathrm{b}}$ & $2.1^{\mathrm{a}}$ & \\
\hline Control & 18.9 & Lsd & Sulphur & AT & SxAT & & Control & 1.2 & Lsd & Sulphur & AT & SxAT \\
\hline Fertilized & 24.7 & 0.05 & 1.68 & ns & $\mathrm{ns}$ & & Fertilized & 1.6 & 0.05 & 0.11 & ns & $\mathrm{ns}$ \\
\hline
\end{tabular}

$\mathrm{S}=$ Sulphur, AT= Application times, $\mathrm{SxAT}=$ Sulphur $\mathrm{x}$ Application times, $\mathrm{ns}=$ non significant, Lsd=Least significant difference test Means of same category followed by different alphabets reveal significant differences among mean values $(\mathrm{P}<0.05)$ using least significant difference test. 
The $60 \mathrm{~kg} \cdot \mathrm{ha}^{-1}$ sulphur application enhanced the glucosinolate content of canola, the safe and acceptable limit, which is $30 \mu \mathrm{mol} \cdot \mathrm{g}^{-1}$. Sulphur is involved in the synthesis of chlorophyll and also required in Cruciferae for the synthesis of volatile oil which accumulates as glucosinolate (Marschner 1986 and Ahmad et al., 2007).

\subsection{Erucic acid (\%)}

The mean values for the data showed that sulphur application enhanced erucic acid (1.6\%) compared to the control $(1.2 \%)$. Significantly higher erucic acid $(2.1 \%)$ was recorded for $75 \mathrm{~kg}$ sulphur $\cdot \mathrm{ha}^{-1}$ (Table. 2). The application times and the interaction of sulphur $\mathrm{x}$ application times was found to be non significant for the erucic acid (\%) of canola seeds. However, erucic acid gradually increased with increasing doses of sulphur (Table 2). Manaf and Fayyaz (2006) reported that eurcic acid was at its maximum when the highest dose of sulphur $\left(25 \mathrm{~kg} \cdot \mathrm{ha}^{-1}\right)$ was applied. Non-essential fatty acids like palmitic, stearic and erucic acid were increased in the canola seed with decreased sulphur levels (Begum et al., 2015).

\subsection{Oil content $(\%)$}

The sulphur levels significantly affected the oil content in canola seeds (Table 3). The comparison of sulphur fertilized plots with the control plots showed that the sulphur fertilized plots obtained significantly higher oil contents $(44.1 \%)$ than the control plots (41.1\%) (Table 3). The oil content was enhanced from 42.8 to $45.2 \%$ as the sulphur rate was boosted up to $60 \mathrm{~kg} \cdot \mathrm{ha}^{-1}$. Kumar and Trivedi, (2012) recorded increasing oil percentages with increasing sulphur applications. However, a further sulphur application of up to $75 \mathrm{~kg} \cdot \mathrm{ha}^{-1}$ did not enhance the oil content. Application timings and the interaction of S x AT had no significant affect on the oil content. Similar results were obtained in earlier studies by Mailer et al., (1989), who concluded that sulphur application enhanced the oil content of canola. The oil contents of canola were enhanced by sulphur application up to $30-50 \mathrm{~kg} \cdot \mathrm{ha}^{-1}$ (Subhani et al., (2003); Malhi and Leach, 2000). The control plots showed reduced oil contents compared to the $60 \mathrm{~kg} \cdot \mathrm{ha}^{-1}$ sulphur-applied plots. Higher oil content was in sulphur-applied plots, as oil contains many fatty acids and these fatty acid structures contain sulphur compounds (Malik et al., 2004).

\subsection{Protein content ( $\%)$}

The seed protein content $(\%)$ of canola is the basic parameter with respect to the quality. The statistical analysis of the data indicated that sulphur levels showed a positive influence on protein content $(\%)$ (Table 3). The $60 \mathrm{~kg} \cdot \mathrm{ha}^{-1}$ sulphur application resulted in higher seed protein content $(24.8 \%)$ in canola. Protein content was increased from $22.4 \%$ to $24.8 \%$ when sulphur levels increased from 15 to $60 \mathrm{~kg} \cdot \mathrm{ha}^{-1}$, while protein content decreased $(23.6 \%)$ when the sulphur level was further increased up to $75 \mathrm{~kg} \cdot \mathrm{ha}^{-1}$. Canola seed protein and oil content were increased with increasing doses of sulphur (Kandil and Nadia, 2012). The crops grown without sulphur had lower protein contents $(20.6 \%)$ than the sulphur-treated plots $(23.4 \%)$. The time of application and interaction of S x AT had no significant effect on the protein content in the seeds (Table. 5). The sulphur application enhanced the seed protein contents of canola due to the protein content of rapeseed containing large amounts of amino acids such as cysteine and methionine which are constituents of sulphur (Holmes, 1980). These results confirm the findings of Rashid (1996) in that amino acids (methionine, cystine and cysteine) contain sulphur as an important structural part and therefore essential protein synthesis occurs due to sulphur. The results obtained regarding the response of sulphur application to the protein content of canola seed are also in line with the earlier findings of Wang

TABLE 3. Oil content ( $\%)$ and protein content ( $\%$ ) of canola as affected by sulphur levels and application times

\begin{tabular}{|c|c|c|c|c|c|c|c|c|c|c|c|c|}
\hline \multirow{3}{*}{$\begin{array}{l}\text { Application } \\
\text { times (AT) }\end{array}$} & \multicolumn{6}{|c|}{ Oil content $(\%)$} & \multicolumn{6}{|c|}{ Protein content $(\%)$} \\
\hline & \multicolumn{5}{|c|}{ Sulphur $\left(\mathrm{kg} \cdot \mathrm{ha}^{-1}\right)$} & & \multicolumn{6}{|c|}{ Sulphur $\left(\mathrm{kg} \cdot \mathrm{ha}^{-1}\right)$} \\
\hline & 15 & 30 & 45 & 60 & 75 & Mean & 15 & 30 & 45 & 60 & 75 & Mean \\
\hline Seedling & 43.6 & 43.4 & 45.6 & 45.9 & 44.2 & $1907^{b}$ & 22.6 & 23.5 & 23.3 & 24.9 & 23.5 & 23.5 \\
\hline Bolting & 41.6 & 43.5 & 45.0 & 44.8 & 43.8 & $1998^{a}$ & 22.6 & 22.4 & 23.7 & 24.6 & 23.3 & 23.3 \\
\hline Flowering & 43.3 & 43.5 & 44.0 & 45.0 & 44.2 & $1922^{b}$ & 22.0 & 22.4 & 23.3 & 24.9 & 24.1 & 23.3 \\
\hline Mean & $42.8^{\mathrm{c}}$ & $43.5^{\mathrm{bc}}$ & $44.8^{\mathrm{ab}}$ & $45.2^{\mathrm{a}}$ & $44.0^{\mathrm{abc}}$ & & $22.4^{\mathrm{c}}$ & $22.8^{\mathrm{bc}}$ & $23.4^{\mathrm{bc}}$ & $24.8^{\mathrm{a}}$ & $23.6^{\mathrm{ab}}$ & \\
\hline Control & 41.1 & Lsd & Sulphur & AT & SxAT & & Control & 20.6 & Lsd & Sulphur & AT & SxAT \\
\hline Fertilized & 44.1 & 0.05 & 1.45 & ns & ns & & Fertilized & 23.4 & 0.05 & 1.22 & ns & ns \\
\hline
\end{tabular}

$\mathrm{S}=$ Sulphur, AT= Application times, $\mathrm{SxAT}=$ Sulphur $\mathrm{x}$ Application times, ns=non significant, $\mathrm{Lsd}=$ Least significant difference test 
et al., (1997) who stated that sulphur applied at up to $40 \mathrm{~kg} \cdot \mathrm{ha}^{-1}$ increased the protein content of canola seeds.

\subsection{Oleic acid (\%)}

The data on the oleic acid (\%) of canola as affected by sulphur levels, application timings and their interaction are given in Table 4 . The control plots resulted in less oleic acid $(52.65 \%)$ as compared to the sulphur fertilized plots $(55.82 \%)$. The statistical analysis of the data showed a non significant effect of sulphur levels and application timing on the oleic acid (\%) of canola. Ahmed and Abdin (2000), concluded that sulphur levels had no significant effect on oleic acid. However, oliec acid $(55.23 \%$ to $56.18 \%)$ was increased with increasing sulphur doses from $15-75 \mathrm{~kg} \cdot \mathrm{ha}^{-1}$. Maximum oleic acid $\left(229.6 \mathrm{mg} \cdot \mathrm{g}^{-1}\right)$ was obtained from sulphurtreated plots as compared to the control (Shoja et al., 2018). Maximum oleica acid contents were observed at $60 \mathrm{~kg} \cdot \mathrm{ha}^{-1}$ when applied at the bolting stage. Oleica acid was increased when sulphur doses were increased from $30-60 \mathrm{~kg} \cdot \mathrm{ha}^{-1}$ (Ray et al., 2015).

TABLE 4. Oleic acid (\%) and linoleic acid (\%) of canola as affected by sulphur levels and application times

\begin{tabular}{|c|c|c|c|c|c|c|c|c|c|c|c|c|}
\hline \multirow{3}{*}{$\begin{array}{l}\text { Application } \\
\text { tmes (AT) }\end{array}$} & \multicolumn{6}{|c|}{ Oleic acid (\%) } & \multicolumn{6}{|c|}{ Linoleic acid (\%) } \\
\hline & \multicolumn{6}{|c|}{ Sulphur $\left(\mathrm{kg} \cdot \mathrm{ha}^{-1}\right)$} & \multicolumn{6}{|c|}{ Sulphur $\left(\mathrm{kg} \cdot \mathrm{ha}^{-1}\right)$} \\
\hline & 15 & 30 & 45 & 60 & 75 & Mean & 15 & 30 & 45 & 60 & 75 & Mean \\
\hline Seedling & 54.33 & 56.40 & 55.63 & 55.05 & 56.20 & 55.52 & 10.7 & 10.6 & 10.4 & 10.5 & 10.4 & 10.5 \\
\hline Bolting & 55.90 & 55.40 & 56.08 & 56.38 & 56.78 & 56.11 & 10.3 & 10.5 & 10.6 & 10.9 & 10.5 & 10.5 \\
\hline Flowering & 55.48 & 54.85 & 56.38 & 56.98 & 55.55 & 55.85 & 9.9 & 10.1 & 10.8 & 10.9 & 10.3 & 10.4 \\
\hline Mean & 55.23 & 55.55 & 56.03 & 56.13 & 56.18 & & 10.3 & 10.4 & 10.6 & 10.8 & 10.4 & \\
\hline Control & 52.65 & Lsd & Sulphur & AT & SxAT & & Control & 9.5 & Lsd & Sulphur & $\mathrm{AT}$ & SxAT \\
\hline Fertilized & 55.82 & 0.05 & ns & ns & ns & & Fertilized & 10.5 & 0.05 & ns & ns & ns \\
\hline
\end{tabular}

$\mathrm{S}=$ Sulphur, AT = Application times, $\mathrm{SxAT}=$ Sulphur $\mathrm{x}$ Application times, $\mathrm{ns}=$ non significant, $\mathrm{Lsd}=$ Least significant difference test Means of same category followed by different alphabets reveal significant differences among mean values $(\mathrm{P}<0.05)$ using least significant difference test.

TABLE 5. Analysis of variance for seed yield $\left(\mathrm{kg} \cdot \mathrm{ha}^{-1}\right)$, biological yield $\left(\mathrm{kg} \cdot \mathrm{ha}{ }^{-1}\right)$, glucosinolate $\left(\mu \mathrm{mol} \cdot \mathrm{g}^{-1}\right)$, erucic acid $(\%)$, oil content $(\%)$, protein content $(\%)$, oleic acid $(\%)$, and linolec acid $(\%)$ of canola as affected by sulphur levels and application times

\begin{tabular}{|c|c|c|c|c|c|c|c|c|c|}
\hline Source of variance & D.F. & $\begin{array}{c}\text { Seed yield } \\
\left(\mathrm{kg} \cdot \mathrm{ha}^{-1}\right)\end{array}$ & $\begin{array}{c}\text { Biological } \\
\text { yield }\left(\mathrm{kg}^{\prime} \mathrm{ha}^{-1}\right)\end{array}$ & $\begin{array}{c}\text { Glucosinolate } \\
\left(\mu \mathrm{mol} \cdot \mathrm{g}^{-1}\right)\end{array}$ & $\begin{array}{c}\text { Erucic } \\
\text { acid (\%) }\end{array}$ & $\begin{array}{l}\text { Oil content } \\
(\%)\end{array}$ & $\begin{array}{c}\text { Protein } \\
\text { content (\%) }\end{array}$ & $\begin{array}{c}\text { Oleic } \\
\text { acid (\%) }\end{array}$ & $\begin{array}{l}\text { linoleic } \\
\text { acid (\%) }\end{array}$ \\
\hline Rep & 3 & 1078.52 & 1745287.04 & 4.19 & 0.01 & 6.04 & 2.44 & 2.39 & 0.08 \\
\hline Treatments $(\mathrm{T})$ & 15 & $847831.51^{* *}$ & $3518813.50^{*}$ & $64.92^{* *}$ & $0.33^{* *}$ & $6.50^{*}$ & $5.07^{*}$ & $4.54^{* *}$ & $0.52^{*}$ \\
\hline Control Vs Fertilized & (1) & $2450235.16^{* *}$ & $16611081.67^{* *}$ & $128.12^{* *}$ & $0.54^{\mathrm{ns}}$ & $33.71^{* *}$ & $28.53^{* *}$ & $37.76^{* *}$ & $3.58^{* *}$ \\
\hline Sulphur Levels (S) & (4) & $2537405.12^{* *}$ & $6112988.54^{* *}$ & $204.12^{* *}$ & $1.06^{* *}$ & $11.46^{*}$ & $10.29^{* *}$ & $2.05^{\mathrm{ns}}$ & $0.42^{\mathrm{ns}}$ \\
\hline $\begin{array}{l}\text { Application } \\
\text { timings (AT) }\end{array}$ & (2) & $47777.06^{* *}$ & $1843977.92^{\mathrm{ns}}$ & $0.46 \mathrm{~ns}$ & $0.01^{\mathrm{ns}}$ & $3.33^{\mathrm{ns}}$ & $0.37^{\mathrm{ns}}$ & $1.72^{\mathrm{ns}}$ & $0.13^{\mathrm{ns}}$ \\
\hline $\begin{array}{l}\text { Sulphur x } \\
\text { Application time }\end{array}$ & (8) & $2757.86^{\mathrm{ns}}$ & $1003901.35^{\mathrm{ns}}$ & $3.53^{\text {ns }}$ & $0.01^{\mathrm{ns}}$ & 1.42 & 0.71 & $2.34^{\mathrm{ns}}$ & 0.28 \\
\hline Error & 45 & 1881.54 & 1578991.76 & 4.20 & 0.02 & 3.11 & 2.20 & 1.84 & 0.25 \\
\hline Total & 63 & & & & & & & & \\
\hline
\end{tabular}

$*$ Significant at $5 \%$ level of probability, ${ }^{* *}=$ Significant at $1 \%$ level of probability, ns $=$ non significant, all parameter presents their sum of squares

TABLE 6. Co-efficient of variance (C.V) for seed yield $\left(\mathrm{kg} \cdot \mathrm{ha}^{-1}\right)$, biological yield $\left(\mathrm{kg} \cdot \mathrm{ha} \mathrm{a}^{-1}\right)$, glucosinolate $\left(\mu \mathrm{mol} \cdot \mathrm{g}^{-1}\right)$, erucic acid $(\%)$, oil content $(\%)$, protein content $(\%)$, oleic acid $(\%)$, and linoleic acid $(\%)$ of canola as affected by sulphur levels and application times

\begin{tabular}{lcccccccc}
\hline Parameters & Seed yield & Biological yield & Glucosinolate & Erucic acid & Oil content & Protein content & Oleic acid & Linoleic acid \\
\hline C.V \% & 2.29 & 12.03 & 8.40 & 8.65 & 2.44 & 6.38 & 2.44 & 4.83 \\
\hline
\end{tabular}




\subsection{Linoleic acid (\%)}

Sulphur levels, time of application and their interaction have no significant effects on the linoliec acid of canola (Table 4). A lower linoleic acid content $(9.5 \%)$ was found in the control plots than the plots fertilized with sulphur $(10.5 \%)$. The results are in line with those of Malhi and Gill (2002), and Malhi and Leach (2000). Increasing doses of sulphur from $15-60 \mathrm{~kg} \cdot \mathrm{ha}^{-1}$ increased linoliec acid (10.3-10.8). However, further a increase beyond 60 $\mathrm{kg}$ sulphur ha- ${ }^{-1}$ decreased the linoliec acid content. Ray et al., (2015) reported that increasing sulphur doses from $30-60 \mathrm{~kg} \cdot \mathrm{ha}^{-1}$ increased linoleic acid percentage. Manaf and Hassan 2006 concluded that linolienic acid was increased when sulphur fertilization increased from $15-25 \mathrm{~kg} \cdot \mathrm{ha}^{-1}$. Sulphur applied at seedling and bolting stage induced more linoliec acid (10.5) compared to flowering stage.

\section{CONCLUSIONS}

The application of sulphur at the rate of $60 \mathrm{~kg} \cdot \mathrm{ha}^{-1}$ produced higher yield and better oil quality in canola seeds. Sulphur application at the bolting stage produced a higher yield and oil components in canola seeds. It is recommended that sulphur be applied at the rate of $60 \mathrm{~kg} \cdot \mathrm{ha}^{-1}$ in the bolting stage to enhance the yield and oil quality of canola.

\section{ACKNOWLEDGMENTS}

The research team are thankful to the Farm Director, The University of Agriculture Peshawar, for providing seeds and harvesting of the canola crop. The authors wish to thank the Nuclear Institute for Food \& Agriculture, Peshawar for conducting the analyses.

\section{REFERENCES}

Ahmed A, Abdin MZ. 2000. Effect of sulphur application on lipid, RNA and fatty acid content in developing seeds of rapeseed (Brassica campestris L.). Pl. Sci. 150, 71-76. https://doi.org/10.1016/S0168-9452(99)00167-3

Ahmad G, Jan A, Arif M, Jan MT, Khattak RA. 2007. Influence of nitrogen and sulphur fertilization on quality of canola (Brassica napus L.) under rainfed conditions. J. Zhejiang Univ. Sci. B 8, 731-737. https://doi.org/10.1631/jzus.2007. B0731

Ahmad N, Muhammad A, Munir I, Shah Z, Basir A. 2015. Characterization of rapeseed germplasm for various quality parameters. American-Eurasian J. Agric. Environ. Sci. 15, 2466-2472.

Ahmad N, Saleem MT, Rashid M, Jalil A. 1994. Sulphur status and crop response in Pakistan soils. National Fertilizer Development Center. Pub. No. 7/94. Planning and Development Division, Islamabad. PP. 1-5.

Begum F, Hossain F, Mondal MRI. 2012. Influence of sulphur on morphophysiological and yield parameters of rapeseed (Brassica campestris L.). Bangladesh J. Agric. Res. 37, 645-652.

Begum F, Hossain F, Islam MM, Mondal MRI. 2015. Effect of sulphur on biochemical parameters of rapeseed
(Brassica Campestris L.) in grey terrace soil. Archives Agro. Soil Sci. 62, 261-276. https://doi.org/10.1080/03650340.20 15.1045496

Chauhan DR, Paroda S, Ram M. 1996. Response of Indian mustard (Brassica juncea) to biofertilizers, $\mathrm{S}$ and $\mathrm{N}$ fertilization. Indian J. Agron. 41, 621-623.

GOP. 2014. Economic Survey Report. (2013-14). Govt. of Pak. Finance Division, Islamabad. P, 1-18.

Grombacher A, Nelson L, 1992. Canola Production. A University of Nebraska Neb Guide Publication, No. G921076-A. Cooperative Extension, Institute of Agriculture and Natural Resources, University of Nebraska-Lincoln.

Kandil H, Gad N. 2012. Growth and oil production of canola as affected by different sulphur sources. J. Basic. Appl. Sci. Res. 2, 5196-5202.

Hassan FU, Manaf A, Qadir G, Basra SMA, 2007. Effects of sulphur on seed yield, oil, protein and glucosinolates of canola cultivars. Int. J. Agric. Biol. 9, 504-508.

Hocking PJ, Pinkerton A, Good A, 1996. Recovery of fieldgrown canola from sulphur deficiency. Aust. J. Exp. Agric. 36, 79-85.

Holmes MRJ. 1980. Nitrogen; In Nutrition of the oilseed rape crop. Applied Sci Pub Barking Essex England. P.21-67.

Jan A, Ahmad G, Jan T, Jamal M, Subhan F. 2008. Oil yields of canola as affected by $\mathrm{N}$ and $\mathrm{S}$ levels and methods of application under rainfed conditions. Sarhad J. Agric. 24, 1-10.

Jan MT, Shah P, Hoolinton PA, Khan MJ, Sohail Q. 2009. Agriculture research: Design and Analysis: Deptt. of Agronomy, NWFP Agric. Uni. Peshawar, Pakistan.

Khandkar MR, Malviya PK, Nigam KB. 1991. Influence of N and S applications on mustard (Brassica juncea L.) in vertisol. Res. Devel. Rep. 8, 189-190.

Kumar R. Trivedi S.K. 2012. Effect of levels and sources of sulphur on yield, quality and nutrient uptake by mustard (Brassica juncea). Progressive Agriculture, Internat. J. 12, 69-73.

Mailer RJ. 1989. Effects of applied sulphur on glucosinolate and oil concentration in the seeds of rape (Brassica napus L.) and turnip rape (Brassica rapa L.). Aust. J. Agric. Res. 40, 617-624.

Malhi H, Leach D. 2000. Restore canola yields by correcting sulphur deficiency in the growing season. Proc. $12^{\text {th }}$ annual meeting and conference "Sustainable farming in the new millennium". Saskatchewan Soil Conservation Association, Regina, SK., Canada.

Malhi SS, Gill KS. 2002. Effectiveness of sulphate-S fertilization at different growth stages for yield, seed quality and S uptake of canola. Can. J. Plant Sci. 82, 665-674.

Malik MA, Aziz I, Khan HZ, Wahid MA. 2004. Growth, seed yield and oil content response of canola (Brassica napus L.) to varying levels of sulphur. Internat. J. Agric. Biol. 6,1153-1155.

Marschner H. 1986. Functions macronutrients \& micronutrients, Mineral nutrition of higher plants. Academic Press Inc. London, U.K. pp, 1- 674.

Varényiová M, Ducsay L, Ryant P. 2017. Sulphur nutrition and its effect on yield and oil content of oilseed rape (Brassica Napus L.). Acta Univ. Agric. Silvic. Mende. Brun. 65, 555-562. https://doi.org/10.11118/actaun201765020555

Manaf A, Fayyaz UH. 2006. Effects of sulphur on fatty acid accumulation in brassica cultivars. Int. J. Agric. Biol. 8, 588-592.

MNFS\&R. 2013-14. Ministry of National Food Security and Research, Agric. Statistics of Pakistan. Govt. of Pak, Economic Wing, Islamabad, pp, 1-166.

Muhammad S, Khalil IA, Khan S. 1991. Fatty acid composition of rape and mustard oilseed cultivars. Sci. Khyber. 4, 29-36.

Ray K, Sengupta K, Pal AK, Banerjee H. 2015. Effects of sulphur fertilization on yield, $S$ uptake and quality of Indian mustard under varied irrigation regimes. Plant Soil Environ. 61, 6-10. https://doi.org/10.17221/860/2014-PSE

Rashid A. 1996. Secondry and micronutrients. In A. Rashid, Q. S. Memon, E. Bashir and R. Band (Eds.) Soil Science. National Book Foundation; Islamabad, p. 341-372.

Rękas A, Siger A, Wroniak M, Scibisz I. 2017. Chemical composition and resistance to oxidation of high-oleic rapeseed 
oil pressed from microwave pre-treated intact and dehulled seeds. 2107. Grasas Aceites 68, e225. https://doi. org/10.3989/gya.0775171

Sawan ZM, Hafez SA, Basyony AE, Alkassas AR. 2007. Nitrogen, potassium and plant growth retardant effect on oil content and quality of cotton seed. Grasas Aceites $\mathbf{5 8}$, 243-251.

Shoja T, Majidian M, Rabiee M. 2018. Effects of zinc, boron and sulphur on grain yield, activity of some antioxidant enzymes and fatty acid composition of rapeseed (Brassica napus L.). Acta Agri. Slov. 111, 73-84. https://doi. org/10.14720/aas.2018.111.1.08
Subhani A, Shabbir G, Fazil M, Mahmood A, Khalid R, Cheema NM. 2003. Role of sulphur in enhancing the oil contents and yield of rapeseed under medium rainfed conditions. Pak. J. Soil Sci. 22, 50-53.

Uncu O, Ozen B, Tokatli F. 2019. Mid-infrared spectroscopic detection of sunflower oil adulteration with safflower oil. Grasas Aceites 70, e290. https://doi.org/10.3989/gya.0579181

Wang QR, Pinkerton A, Hocking P, Wang QR. 1997. Effects of sulphur top-dressing on yield and quality of a double-low rapeseed (Brassica napus L.). Oil Crop. China. 19, 53-57.

Weiss EA. 1983. Rapeseed. In Oilseed Crops, Longman Group, New York, P.161-215. 